\title{
Linking soil erosion to on-site financial cost: lessons from watersheds in the Blue Nile basin
}

\author{
T. Erkossa ${ }^{1}$, A. Wudneh ${ }^{2}$, B. Desalegn ${ }^{3}$, and G. Taye ${ }^{4}$ \\ ${ }^{1}$ International Water Management Institute, P. O. Box 5689, Addis Ababa, Ethiopia \\ ${ }^{2}$ Natural Resources Management Course Team, Madawalabu University, \\ P. O. Box 247, Robe-Bale, Ethiopia \\ ${ }^{3}$ Department of Land Resource Management and Environmental Protection; \\ Mekelle University, P. O. Box 23, Mekelle, Ethiopia \\ ${ }^{4}$ Bahir Dar University, College of Agriculture and Environmental Science, \\ P. O. Box 78, Bahir Dar, Ethiopia
}

Correspondence to: T. Erkossa (t.erkossa@cgiar.org)

Received: 9 January 2015 - Published in Solid Earth Discuss.: 4 February 2015

Revised: 30 April 2015 - Accepted: 30 April 2015 - Published: 22 June 2015

\begin{abstract}
The study was conducted in three watersheds (Dapo, Meja and Mizewa) in the Ethiopian part of the Blue Nile Basin to estimate the on-site cost of soil erosion using the productivity change approach, in which crop yield reduction due to plant nutrients lost with the sediment and runoff has been analysed. For this purpose, runoff measurement and sampling was conducted during the main rainy season of 2011 at the outlet of two to three sub-watersheds in each watershed. The sediment concentration of the runoff, and $\mathrm{N}$ and $\mathrm{P}$ contents in runoff and sediment were determined. Crop response functions were developed for the two plant nutrients based on data obtained from the nearest Agricultural Research Centres. The response functions were used to estimate crop yield reduction as a result of the lost $\mathrm{N}$ and $\mathrm{P}$ assuming there is no compensation through fertilization. The results show a significant yield reduction and resultant financial loss to the farmers. Considering only grain yield of maize (Zea mays), farmers at Dapo annually lose about USD $220 \mathrm{ha}^{-1}$ and $150 \mathrm{ha}^{-1}$ due to the loss of $\mathrm{N}$ and $\mathrm{P}$, respectively. In view of the importance of the crop residues, including as feed, the loss can be even greater. The study demonstrated that in addition to the long-term deterioration of land quality, the annual financial loss suffered by farmers is substantial. Therefore, on farm soil and water conservation measures that are suitable in biophysical and socio-economic terms in the landscapes and beyond need to be encouraged.
\end{abstract}

\section{Introduction}

Soil erosion is a global environmental threat that reduces the productivity of all natural ecosystems including agriculture (Kertész, 2009; Pimentel and Burgess, 2013; Leh et al., 2013). Erosion-induced soil quality deterioration is prevalent throughout the world (Harden, 2001; Zhao et al., 2013), impeding the global food and economic security. The challenges of soil erosion are more severe in the heavily populated, under-developed, and ecologically fragile areas of the world (Young, 1993; FAO and UNEP, 1999), where the adaptation capacity is weak (Cerdà, 2000; Leh et al., 2013). Tesfahunegn (2013) argues - citing Lal (1981) and Eswaran et al. (2001) - that misuse of soils, resulting from a desperate attempt by farmers to increase production for the growing population exacerbates soil quality degradation, and he further suggests that severity of such degradation is higher in developing countries where the economy mainly depends on agriculture. Soil erosion by water is the greatest factor limiting soil productivity and impeding agricultural enterprises in the humid tropical regions (Sunday et al., 2012). The resourcepoor farmers in sub-Saharan Africa (SSA) are exposed to the pressures of soil quality deterioration, the effect of which is aggravated by their limited access to the resources that are necessary for adaptation. In the Ethiopian Highlands, reduced agricultural productivity and poverty because of soil quality degradation are widespread (Erkossa et al., 2006). 
Inappropriate land use, in which land is not used according to its suitability, and poor farming practices are the major factors leading to erosion-induced soil quality deterioration in the highlands of Ethiopia (Adimassu et al., 2014; Angassa et al., 2014; Belay et al., 2013; Erkossa et al., 2005) and in other parts of the world (Bravo Espinosa et al., 2014), which pose socio-economic and environmental challenges. Studies conducted in northern highlands of the country show that removal of the natural vegetation for expansion of agricultural and rangeland has led to increased soil losses and growth of rock outcrops, which leads to nutrient depletion and lowering of agricultural yields (Belaly et al., 2014; Mulugeta et al., 2005; Woldeamlak and Stroosnijder, 2003). Often farmers attempt to produce their traditional crops using techniques that are not necessarily suitable for the new land they access through such expansion.

Soil erosion has on-site and off-site effects. The direct onsite effect is related to agronomic productivity of plants (Lal, 1998), which is often linked to nutrient loss with runoff and sediment. Haileslassie et al. (2005) estimated an annual nutrient depletion rate of $122 \mathrm{~kg} \mathrm{~N}, 13 \mathrm{~kg} \mathrm{P}$ and $82 \mathrm{~kg} \mathrm{~K} \mathrm{ha}^{-1}$ from the Ethiopian highlands. Further, Adimassu et al. (2012) estimated an annual loss of $47.8 \mathrm{~kg} \mathrm{~N}, 0.60 \mathrm{~kg} \mathrm{P}_{2} \mathrm{O}_{5}$ and 0.40 $\mathrm{K}_{2} \mathrm{O} \mathrm{ha}^{-1}$ which he attributed to soil erosion alone. As a consequence of both soil erosion and nutrient depletion, more than 30,000 ha of the country's cropland are estimated to become out of production annually (Grepperud, 1996). Quantifying the economic effects of these soil and nutrient losses, especially before the land is completely out of production remains a daunting challenge. Such information helps to substantiate investment on land management measures for the short- and long-term benefits to both on-site and off-site land users. Clearly, in the long-term, improved land and water management brings economic advantages to the land users, but farmers often resist adopting such measures because they lack relevant evidence on how land degradation impacts their earnings and livelihood (Telles et al., 2013).

Availability of plant nutrients in the soil limits land and water productivity in areas where absolute quantities of water are not limiting, but even in moisture-deficient areas it can be more limiting than water (Breman, 1998). Therefore, management practices that affect the nutrient content of soils directly affect farmers' income. Soil nutrient depletion is an important on-site effect of soil erosion (Bojö and Cassells, 1995; Verstraeten and Poesen, 2000). Such effects can be plausible to farmers and policy makers if expressed in terms of immediate financial cost.

According to Telles et al. (2013), the on-site costs of soil erosion can be estimated using the cost of replacement for the nutrients lost, normally macronutrients calculated on the basis of market prices for commercial fertilizers and the quantity necessary to replace the lost nutrients, plus the application cost. This approach presumes that farmers replace the lost nutrients through fertilization, which is not often the case in subsistent farming systems in developing countries.
In such cases, it can be argued that rather the cost of not replacing the lost nutrients should be estimated and used as a proxy for the on-site cost of erosion. In line with this, Telles et al. (2013) suggest the use of estimated yield reduction as a measure of productivity loss resulting from soil limitations, including loss of the essential nutrients. The objective of this study was to quantify the essential nutrients lost due to soil erosion and to estimate the resultant crop yield and household income losses.

\section{Materials and methods}

\subsection{Study sites}

The study was conducted in three watersheds - Dapo, Meja and Mizewa - with two sub-watersheds for the first and three sub-watersheds each for the last two, all in the Blue Nile Basin (Fig. 1). All the watersheds, except the lower part of Dapo, are situated in the highlands (above $1500 \mathrm{~m}$ a.s.1.) based on the Ethiopian agro-ecological classification systems, but farmers in the districts traditionally classify these areas into high, middle and low lands. The altitude range of each traditional class was later determined using GPS handsets (Table 1). The sites receive relatively high rainfall ranging from $900 \mathrm{~mm}$ at Meja to over $2000 \mathrm{~mm}$ at Dapo, the major part of which is received during the main rainy season in summer (May to September) (Fig. 2).

\subsection{Farming systems}

Crop-livestock mixed cropping agriculture is the dominant livelihood, while the major crops grown vary between and within the watersheds based on altitude (Table 1). While irrigation is limited to the valley bottoms and on the sides of streams, rainfed cropping of maize (Zea mays), barley (Hordium vulgarae), wheat (Triticum aestivum), tef (Eragrostis tef Zucca), and sorghum (Sorghum bicolor) is widespread in all the sites but potato (Solanum tuberosum) is also an important crop in the highland part of Meja. Population pressure, land degradation, inefficient use of water (rainfed and irrigated) and inappropriate land use and land and water management practices, are among the common challenges to the sustainability of the watersheds (Erkossa et al., 2009).

\subsection{Runoff measurement}

Runoff was measured 3 times a day (at 8 a.m., 12 p.m. and 6 p.m.) and averaged to get a daily flow during the rainy season (which was at least 90 days) in 2011 at two to three selected gauging sites in each watershed. Discharge was measured using the Velocity-Area Method (Chitale, 1974). A current metre (Model 0012B Surface Display Unit and Model 002 Flow Meter) was used to measure the flow velocity $(V)$. The flow depth at predefined cross-sections was mea- 


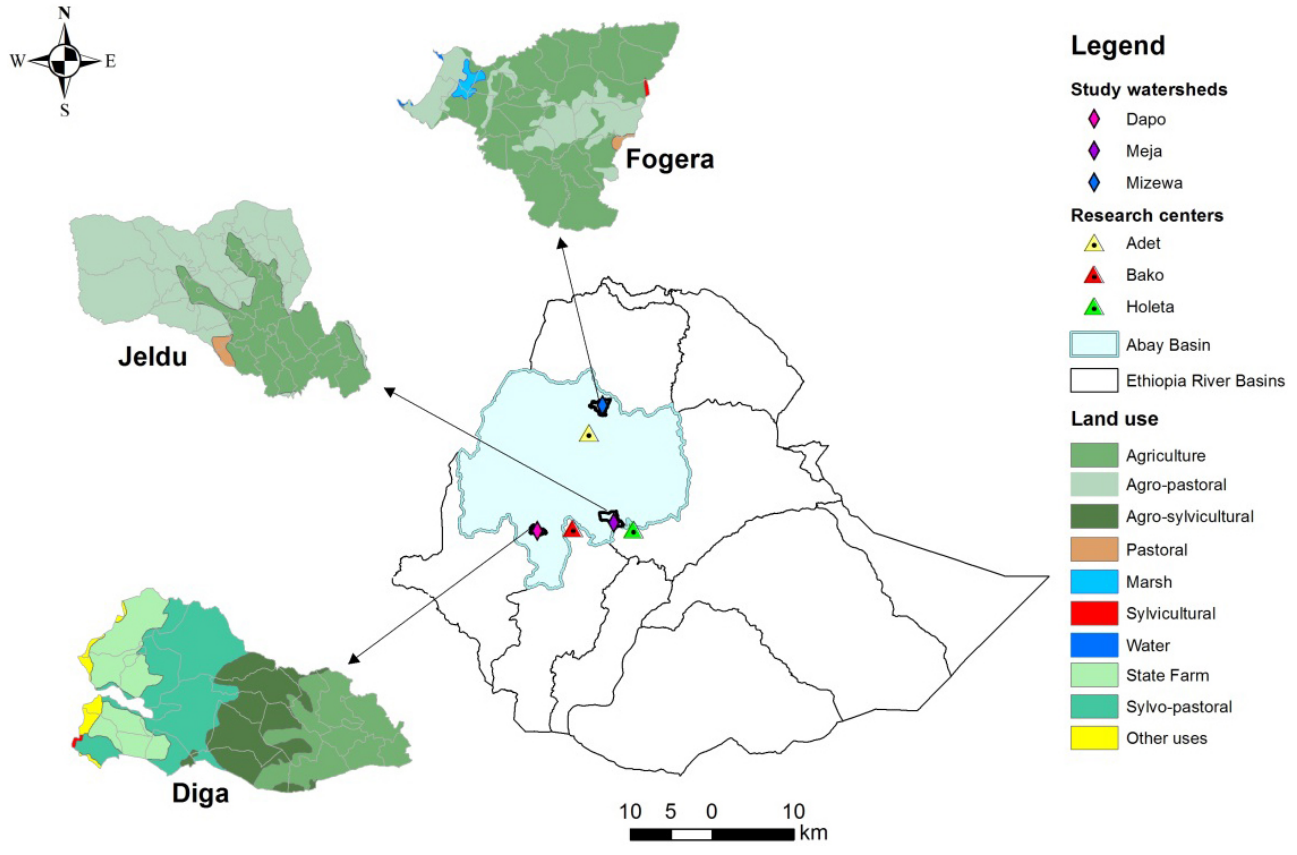

Figure 1. Location and land use map of the study sites with the nearest agricultural research centres.

Table 1. Description of the three study watersheds based on office of agriculture annual report (2006 to 2010), ILRI Baseline Survey (2010) and own survey.

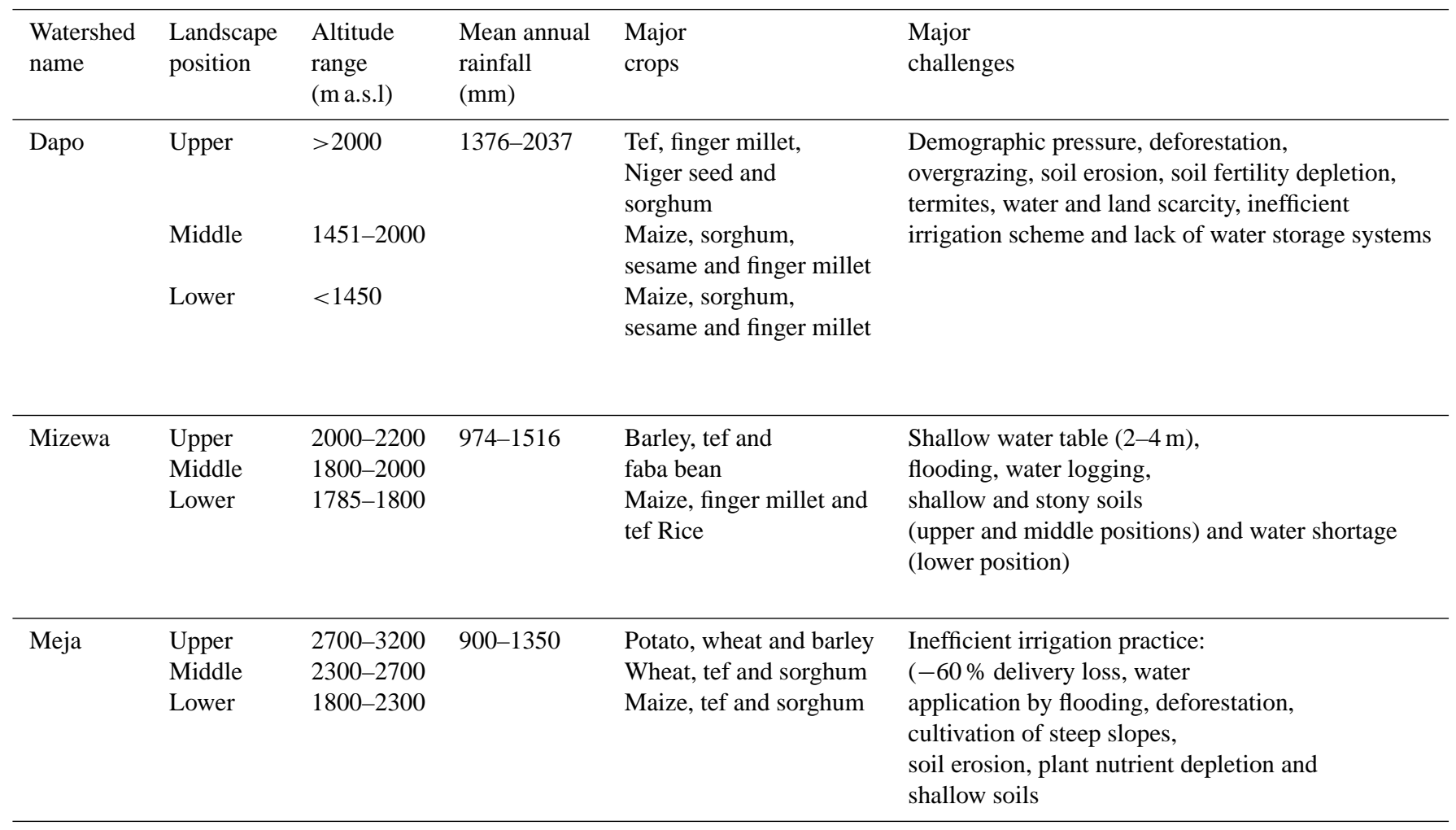




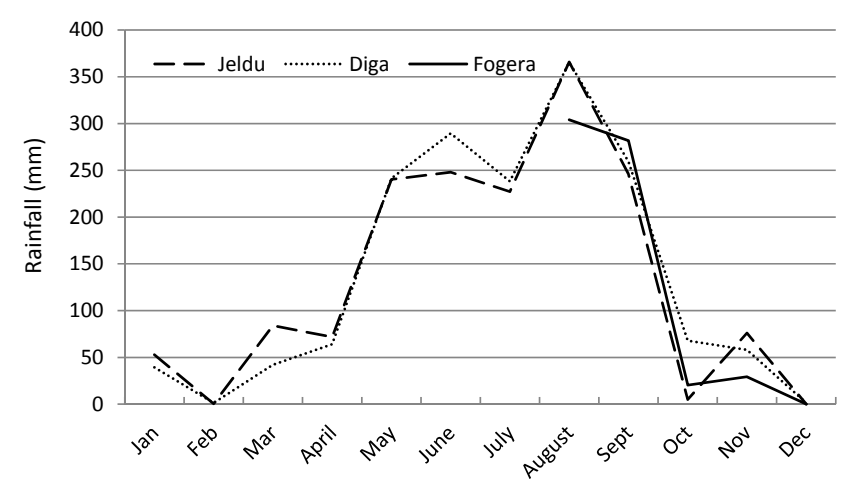

Figure 2. Rainfall of the study sites in 2011 with Fogera's data only for August to December.

sured using a graduated wading rod simultaneously at several points spaced at varying intervals depending on the width of the stream. The cross-sectional area $\left(A_{i}\right)$ of the flow was calculated using the flow depth $\left(H_{i}\right)$ at each point. The average flow velocity at each point $\left(V_{i}\right)$ and the average discharge at each sub-cross-sectional area $\left(Q_{i}\right)$ were calculated using Eq. (1) and the total flow $(Q)$ passing the outlet was calculated using Eq. (2):

$Q_{i}=V_{i} \cdot A_{i}$

$Q=\sum_{i=1}^{n} q_{i}$

where:

$H_{i}=$ flow depth at each cross-section (m)

$A_{i}=$ cross-sectional area at each point $\left(\mathrm{m}^{2}\right)$

$q_{i}=$ discharge at each cross-sectional area $\left(\mathrm{m}^{3} \mathrm{~s}^{-1}\right)$

$V_{i}=$ flow velocity at each cross-sectional area $\left(\mathrm{m} \mathrm{s}^{-1}\right)$

$Q=$ Total discharge $\left(\mathrm{m}^{3} \mathrm{~s}^{-1}\right)$.

Steady-flow discharge rating curves (Fig. 3) were developed by fitting the measured water level to discharge in a power curve; water levels were measured throughout the study period using a staff gauge and the discharge was calculated from the equations of the curves:

$Q=c(H+a)^{b}$

where:

$Q=$ discharge $\left(\mathrm{m}^{3} \mathrm{~s}^{-1}\right)$

$H=$ measured water level (m)

$a=$ water level (m) corresponding to $Q=0$

$c=$ coefficients for the relationship corresponding to

the station characteristics

$b=$ coefficient for the power relation of the station characteristics.

\subsection{Runoff sampling and suspended sediment loss estimation}

Depth-integrated runoff samples were collected manually at the outlet of the sub-catchments using $1 \mathrm{~L}$ plastic bottles three times a day. The daily samples were mixed and $2 \mathrm{~L}$ were subsampled and bulked for 10 consecutive days in a $20 \mathrm{~L}$ jerry can and kept in refrigerators at $4^{\circ} \mathrm{C}$ in laboratories. The suspended sediment in the bulked samples was allowed to settle and the clear water at the top was decanted into laboratory beakers. The turbid part remaining at the bottom was filtered using Whatman filter papers number 4 and oven dried and weighed. The suspended sediment concentration of the runoff for each 10 successive days was obtained by dividing the mass of the oven dry sediment by the volume of the runoff during the 10-day interval. The decanted water and that left after filtration were mixed and subsampled for chemical analysis.

\subsection{Estimates of $\mathrm{N}$ and $\mathrm{P}$ losses}

The essential plant nutrient $\mathrm{N}$ and $\mathrm{P}$ content of the suspended sediment and the runoff water was determined following standard procedures for these elements (Table 2). The sum of the nutrients lost associated with the suspended sediments and dissolved in runoff was considered as the total loss of these nutrients during the study period (Eqs. 4-6). Although rainfall started in May, discharge measurement and runoff sampling started in July, after some significant runoff had escaped; thus the total nutrients loss captured during the recording period is only a fraction of what has been lost during the entire rainy season:

Total nutrient loss $(\mathrm{g})=\mathrm{Nu}_{\text {sed }}+\mathrm{Nu}_{\text {runoff }}$

where:

$\mathrm{Nu}_{\text {sed }}=\mathrm{N}$ or P lost with sediment $(\mathrm{g})$

$\mathrm{Nu}_{\text {runoff }}=\mathrm{N}$ or P lost with runoff $(\mathrm{g})$

$\mathrm{Nu}_{\mathrm{sed}}=\sum_{\mathrm{di}=1}^{n} \mathrm{SL}_{\mathrm{di}} \cdot \mathrm{Con}_{\mathrm{dis}}$,

where:

$\mathrm{SL}_{\mathrm{di}}=$ Soil loss during the ten days interval $i\left(\mathrm{kgha}^{-1}\right)$

$\mathrm{Con}_{\text {dis }}=$ Nutrient concentration in sediment during

the ten days interval $i\left(\mathrm{~g} \mathrm{~kg}^{-1}\right)$

$\mathrm{Nu}_{\mathrm{runoff}}=\sum_{\mathrm{di}=1}^{n} Q_{\mathrm{di}} \cdot \mathrm{Con}_{\mathrm{dir}}$,

where:

$Q_{\mathrm{di}}=$ runoff $\left(\mathrm{m}^{3} \mathrm{ha}^{-1}\right)$ during the 10-day interval $i$

$\mathrm{Con}_{\text {dir }}=$ Nutrient concentration in runoff during

the 10-day interval $i\left(\mathrm{gm} \mathrm{m}^{3}\right)$ 

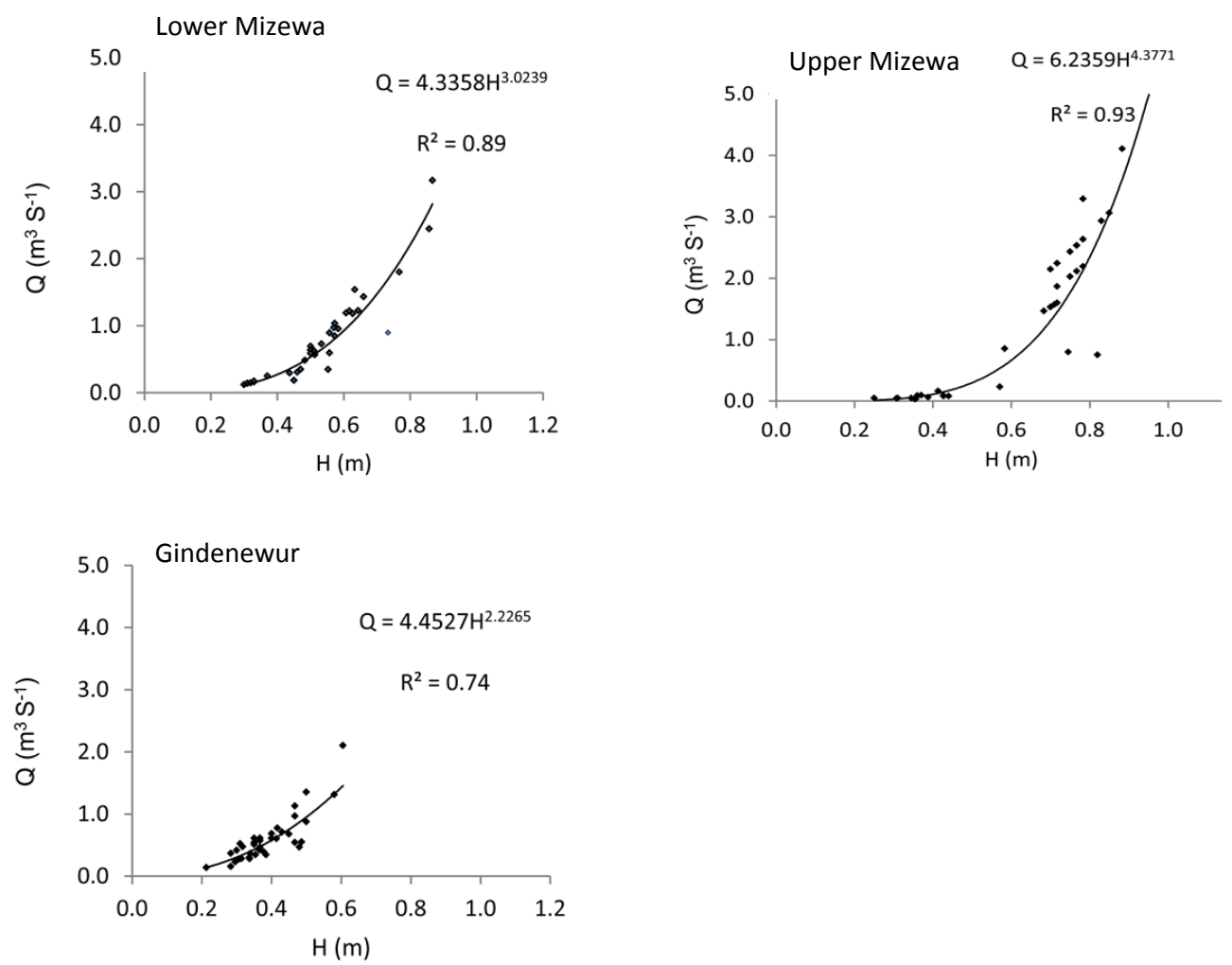

Figure 3. Discharge rating curves for some of the sub-watersheds where $Q$ and $H$ stand for volume in cubic metres per second and flow depth in metres, respectively.

Table 2. Methods and procedures used for the chemical analysis of sediment and water samples.

\begin{tabular}{llll}
\hline Sample & Parameter & Method & Reference \\
\hline \multirow{2}{*}{ Sediment } & $\mathrm{NO}_{3}-\mathrm{N}$ and $\mathrm{NH}_{4}-\mathrm{N}$ & Magnesium oxide-Devarda's alloy & Maiti (2004) \\
& Phosphorus & Olsen & Olsen et al. (1982) \\
\hline \multirow{2}{*}{ Water } & Dissolved $\mathrm{NH}_{4}-\mathrm{N}$ & Phenate method using spectrophotometer & Patnaik (2010) \\
& Dissolved $\mathrm{NO}_{3}-\mathrm{N}$ and phosphorus & Spectrophotometer & Patnaik (2010) \\
\hline
\end{tabular}

\subsection{Estimation of crop yield reduction}

Although nutrient loss rates vary between land use types and prevailing management (Haileslassie et al., 2006) and assessment at watershed level may confound these variations, measurement was made at sub-watershed level. Consequently, comparison can only be made at sub-watershed and watershed levels, instead of in relation to land use and management regimes. Assuming that the nutrient losses are even across the watersheds regardless of the land use and management types (Fig. 4) and further assuming that no compensation through fertilization was made, as is often the case in the areas, the yield reduction due to soil erosion was estimated using the response curves developed for the dominant crops and the two nutrients (FAO, 1999). Maize for Dapo and Mizewa, and potato and barley for Meja were considered as major crops for the assessment. The response functions were developed (Table 3 ) based on unpublished secondary data obtained from the $\mathrm{N}$ and $\mathrm{P}$ application rates studies conducted on these crops under similar agro-ecological conditions by the nearest Agricultural Research Centres (Fig. 1) including Bako, Adet and Holeta for Dapo, Mizewa and Meja, respectively.

The functions were used to estimate the yield that could be obtained with and without application of the nutrients lost as fertilizers and the difference between the two was taken as the net reduction in yield due to the loss of nutrients. The farm gate and local market prices respectively were used for grain and tuber, and the average price (ETB $100 \mathrm{~kg}^{-1}$ ) was 350 for maize and potato and 500 for barley, where the average exchange rate in February 2012 (USD $1=$ ETB 19.89) was used for conversion. The prices of the crops were used 


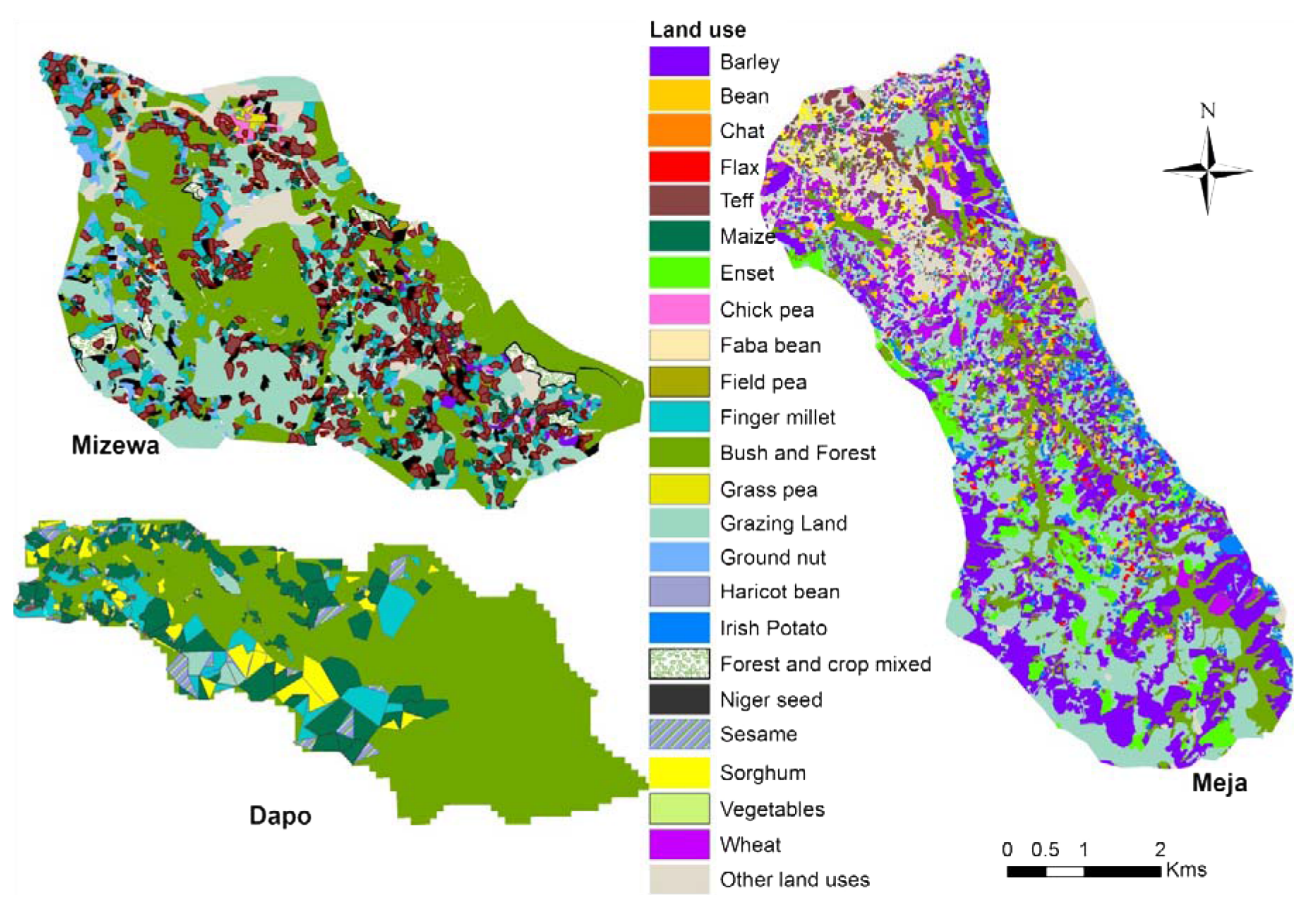

Figure 4. Crop pattern maps of the study watersheds during the study period (2011).

Table 3. Response equations of selected crops to $\mathrm{N}$ and $\mathrm{P}$ application rates $\left(\mathrm{kg} \mathrm{ha}^{-1}\right)$ where $Y$ stands for crop yield $\left(\mathrm{kg} \mathrm{ha}^{-1}\right)$.

\begin{tabular}{llllll}
\hline Location & Crop type & $\begin{array}{l}\text { Response to } \mathrm{N} \\
\text { equation }\end{array}$ & $R^{2}$ & $\begin{array}{l}\text { Response to } \mathrm{P} \\
\text { equation }\end{array}$ & $R^{2}$ \\
\hline Dapo & Maize & $Y=-0.22 \mathrm{~N}^{2}+72.75 \mathrm{~N}+2483$ & 0.72 & $Y=-1.1(0.436 \mathrm{P})^{2}+70.89 \mathrm{P}+2483$ & 0.72 \\
Mizewa & Maize & $Y=-0.29 \mathrm{~N}^{2}+58.6 \mathrm{~N}+2537$ & 0.75 & $Y=-0.55(0.436 \mathrm{P})^{2}+35.84 \mathrm{P}+2691$ & 0.88 \\
Meja & Potato & $Y=-0.001 \mathrm{~N}^{2}+0.31 \mathrm{~N}+16.15$ & 0.71 & $Y=0.005 \mathrm{P}^{2}+0.65 \mathrm{P}+16.54$ & 0.90 \\
& Barley & $Y=-0.412 \mathrm{~N}^{2}+39.94 \mathrm{~N}+1129$ & 0.89 & $Y=-0516 \mathrm{P}^{2}+53.33 \mathrm{P}+1209$ & 0.77 \\
\hline
\end{tabular}

to convert the reduction in yield to financial loss incurred by the farmers.

\section{Results and discussion}

\subsection{Runoff and suspended sediment export}

The total runoff per hectare during the season was highly variable between and within the sites (Table 4), although there was minor difference in terms of the rainfall received during the same period. On average, the highest runoff volume was from Mizewa while the least was from Dapo, which is comparable with that from Meja.

The runoff from the watersheds and the sub-watersheds seems to have been influenced by factors such as topographic characteristics, land use and management practices implemented (Gary and Carmen, 2007; Hartanto et al., 2003). For instance, runoff from Kollu sub-catchment at Meja was 135 times higher than that from Gallessa. A large proportion of
Gallessa is flat and waterlogged, and a major part of it is used for grazing or cultivation of potatoes that are often planted early in the season on contours to cover the land during the peak season, thus increasing water infiltration. In contrast, Kollu is characterized by steep slopes and largely cultivated to cereals that are planted late in the season exposing bare land to erosive force of rainfall and runoff. Therefore, improving land use and management practices, such as growing permanent crops on the steep slopes (Hartanto et al., 2003), contour cultivation (Quinton and Catt, 2004) and early planting to ensure sufficient land cover during the peak rainfall season and implementing soil conservation practices such as soil bunds stabilized with vegetative materials may allow more infiltration of water (Cerdà, 1998) that can be used by the crops during the dry season and reduce loss of soil and water.

The average sediment lost during the study period ranged from $2334 \mathrm{~kg} \mathrm{ha}^{-1}$ at Meja to $5689 \mathrm{~kg} \mathrm{ha}^{-1}$ at Dapo (Fig. 5), and this is lower than most estimates for the Ethiopian highlands where the estimated annual soil erosion rates range 
Table 4. Average runoff and sediment loss during the season from the catchments.

\begin{tabular}{lllll}
\hline Catchment & Sub-catchment & Area (ha) & Runoff $\left(\mathrm{m}^{3} \mathrm{ha}^{-1}\right)$ & $\begin{array}{l}\text { Sediment loss during } \\
\text { the season }\left(\mathrm{kg} \mathrm{ha}^{-1}\right)\end{array}$ \\
\hline \multirow{2}{*}{ Dapo } & Dapo & 1620 & 3196 & 4072 \\
& Chekorsa & 560 & 3900 & 7306 \\
\cline { 2 - 5 } & Average & & 3548 & 5689 \\
\hline \multirow{2}{*}{ Mizewa } & Lower Mizewa & 2664 & 6885 & 3173 \\
& Upper Mizewa & 1870 & 6882 & 1599 \\
& Gindenewur & 715 & 6882 & 2520 \\
\cline { 2 - 5 } & Average & & 6883 & 2431 \\
\hline \multirow{2}{*}{ Meja } & Melka & 9200 & 2707 & 2675 \\
& Kollu & 250 & 8079 & 1847 \\
& Galessa & 160 & 60 & 2481 \\
\cline { 2 - 5 } & Average & & 3615 & 2334 \\
\hline
\end{tabular}

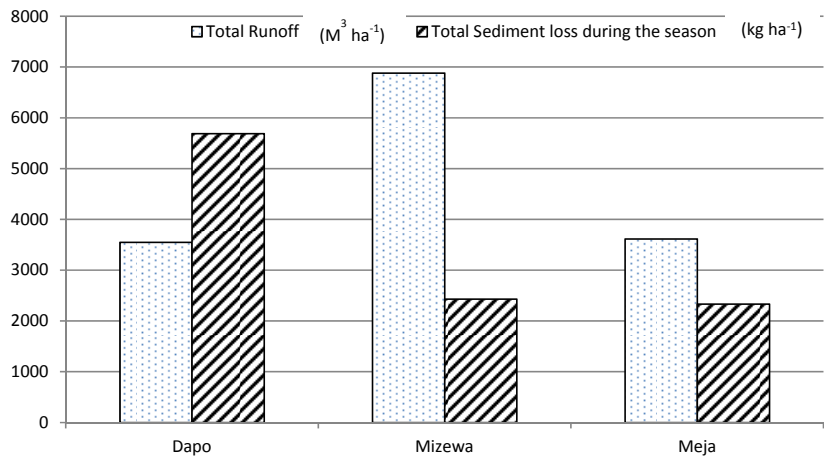

Figure 5. Average runoff in cubic metres per hectare and sediment loss in kilogram per hectare during the measurement period at the study sites.

from as low as $16 \mathrm{tha}^{-1}$ (Gizachew, 1995) to as much as $300 \mathrm{tha}^{-1}$ (Herweg and Stillhardt; 1999 Hurni, 1993). As explained earlier, in all the sites, rainfall started in May, but runoff measurement and sampling began in early July after the most sensitive time in terms of soil erosion has passed. At all the sites, intensive tillage for land preparation which keeps the soil surface bare and vulnerable to the detaching forces of raindrops and runoff starts in April and May depending on the onset of rainfall (Erkossa et al., 2009). Therefore, the sediment loss reported here is only a portion of the total loss. For instance, a modelling effort for the same year using RUSLE revealed an estimated annual soil loss rate of $10 \mathrm{tha}^{-1}, 4 \mathrm{tha}^{-1}$ and $5 \mathrm{tha}^{-1}$ for lower Mizewa, upper Mizewa and Gindenewur sub-catchments, respectively (Getnet, et al., 2013). In addition, not all the sediment that is lost from the upstream fields is delivered to the outlet since part of it is deposited on its way (Pathak et al., 2004). Consequently, the data may not show the full picture and should be interpreted only in relative terms.
In contrast to its lowest runoff, Dapo exhibited the highest sediment loss per unit area during the study period. This may be related to the high rate of active deforestation that exposes topsoil on sloping land to the detaching forces of raindrops and the high transport capacity of runoff created by the steep slope gradient. This is particularly true for Chekorsa sub-catchment in which the peak sediment concentration coincided with the peak runoff (Wudneh et al., 2014). Mizewa revealed lower soil loss than Dapo, despite its highest cumulative runoff. According to Pathak et al (2004), several factors such as storm size, duration and intensity, changes in crop canopy during the season, tillage timing, and changes in grass waterway conditions explain the major parts of the variation in sediment concentration among sub-watersheds. In addition, the lower soil loss from Mizewa can partly be attributed to a longer history of its exposure to accelerated soil erosion which might have led to the armouring effect due to the selective soil erosion by water (Charles and Black, 2001), in which case detachment instead of transportation would be the limiting factor.

\section{2 $\mathrm{N}$ and $\mathrm{P}$ export}

The buildup and depletion, respectively, of plant nutrients from agricultural soil has been a problem in developed and developing countries. Soil erosion and leaching are among the major factors responsible for nutrient depletion from agricultural lands in humid tropical areas in Africa (Henao and Baanante, 1999). The rate of $\mathrm{N}$ and $\mathrm{P}$ loss due to erosion is often related to the rate of runoff and soil erosion (Wu et al., 2012). This study revealed that $\mathrm{N}$ and $\mathrm{P}$ loss was strongly related to the soil loss, in which the highest $\mathrm{N}\left(14 \mathrm{~kg} \mathrm{ha}^{-1}\right)$ and $\mathrm{P}\left(6.8 \mathrm{~kg} \mathrm{ha}^{-1}\right)$ values were from Dapo where the sediment loss was the highest (Table 5). However, while the sediment loss at Dapo was 2.3 times higher than that from Mizewa (the lowest), the $\mathrm{N}$ and $\mathrm{P}$ loss was even higher (6.7 and 3.6 
Table 5. $\mathrm{N}$ and $\mathrm{P}$ export with suspended sediment and dissolved in runoff during the season and the corresponding yield and financial loss (at an average exchange rate in February 2012 of $1 \mathrm{USD}=19.89$ ETB).

\begin{tabular}{|c|c|c|c|c|c|c|c|c|}
\hline \multirow[t]{2}{*}{ Catchment } & \multirow[t]{2}{*}{$\begin{array}{l}\text { Sub- } \\
\text { catchment }\end{array}$} & \multicolumn{2}{|c|}{ Nutrient loss $\left(\mathrm{kgha}^{-1}\right)$} & \multicolumn{2}{|c|}{$\begin{array}{l}\text { Estimated yield loss } \\
\left(\mathrm{kgha}^{-1}\right) \text { due to }\end{array}$} & \multirow[t]{2}{*}{$\begin{array}{l}\text { Crop } \\
\text { type }\end{array}$} & \multicolumn{2}{|c|}{$\begin{array}{l}\text { Financial loss } \\
\left(\mathrm{USDha}^{-1} \mathrm{yr}^{-1}\right)\end{array}$} \\
\hline & & $\mathrm{N}$ & $\mathrm{P}$ & $\mathrm{N}$ & $\mathrm{P}$ & & $\mathrm{N}$ & $\mathrm{P}$ \\
\hline \multirow[t]{3}{*}{ Dapo } & Dapo & 13.6 & 9.3 & 949 & 1421 & \multirow[t]{2}{*}{ Maize } & 171 & 263 \\
\hline & Chekorsa & 14.3 & 4.2 & 1013 & 664 & & 188 & 123 \\
\hline & Average & 14.0 & 6.8 & 981 & 1043 & & 179 & 193 \\
\hline \multirow[t]{6}{*}{ Mizewa } & Lower & 2.3 & 1.8 & 134 & 320 & \multirow[t]{6}{*}{ Maize } & 58 & 138 \\
\hline & Mizewa & & & & & & & \\
\hline & Upper & 1.6 & 1.8 & 93 & 328 & & 40 & 142 \\
\hline & Mizewa & & & & & & & \\
\hline & Gindenewur & 2.3 & 2.1 & 134 & 382 & & 58 & 165 \\
\hline & Average & 2.1 & 1.9 & 120 & 343 & & 52 & 148 \\
\hline \multirow[t]{4}{*}{ Meja } & Melka & 9.0 & 6.0 & 32 & 47 & \multirow[t]{2}{*}{ Barley } & 13 & 19 \\
\hline & Kollu & 17 & 5.0 & 25 & 43 & & 10 & 17 \\
\hline & Galessa & 3.0 & 3.0 & 210 & 340 & Potato & 50 & 81 \\
\hline & Average & 9.7 & 4.7 & 89.0 & 143 & & 24 & 39 \\
\hline
\end{tabular}

times, respectively) compared to that from Mizewa. In part, this may be related to the fact that Dapo is experiencing active expansion of agriculture to forested areas that are rich in these nutrients. Therefore, limiting land use change from forest to agriculture by intensifying productivity in areas already under cultivation may mitigate the loss of sediment and nutrients.

\subsection{Effect of $\mathrm{N}$ and $\mathrm{P}$ losses on crop yield}

The impact of soil erosion on the productive potential of agricultural lands is well known (Pathak et al., 2004), but the magnitude depends on local circumstances. In the study areas, the loss of the essential plant nutrients $\mathrm{N}$ and $\mathrm{P}$ in association with the suspended sediments and runoff during the measurement period and the attendant yield and income losses suffered by farmers were remarkable. Predictably, the maximum yield reduction and resultant financial loss due to the two plant nutrients considered was from Dapo (Table 5) which corresponds to the highest loss of these nutrients, while the least was from Meja. Compared to Meja, the estimated yield reduction due to $\mathrm{N}$ and $\mathrm{P}$ loss from Dapo was 11 and 7 times higher while the corresponding financial loss was 7 and 5 times higher, respectively. The relatively lower financial loss from Dapo is related to the lower market price of maize as compared to barley and potato, which are dominant at Meja.

Despite the apparent under-estimation of the impact since the major part of sediment and nutrient loss was not captured, compared to the average income of the subsistent farmers $\left(60 \mathrm{USD} \mathrm{ha}^{-1}\right.$ ) (IFPRI 2010), the estimated yield reduction and loss of income due to the loss of the two essential nutri- ents can be considered high, regardless of the location considered. The estimate assumes no substitution of the nutrients lost either through external inputs or internal regeneration. However, the use of technologies for compensating the nutrients such as applying more nutrients and using management practices increases production costs, which can still reduce net farm income. However, using soil and water conservation practices that control erosion, these costs can be minimized, which improves the sustainability of the agriculture sector (Montgomery, 2007; Lal, 2006). Soil erosion also brings about a loss of soil quality (Blaschke et al., 2000) including its physical deterioration, which has repercussions both on its nutrient and water holding capacity and thereby on productivity.

In addition to the reduction in crop yield that directly affects the land user, both $\mathrm{N}$ and $\mathrm{P}$ contribute to eutrophication of freshwater bodies that are essential for various ecosystem services (Lewis et al., 2011; Conley et al., 2009), affecting the society at large. Consequently, maintaining or improving water quality in lakes, ponds etc. that may experience manmade eutrophication requires reducing inputs of the nutrients to the water bodies, especially from agricultural lands, where these nutrients are needed by crops in large quantities. Therefore, although controlling runoff and soil erosion should be done on farm lands, farmers need some incentives in addition to reducing yield loss. Other stakeholders that benefit from the avoided risk of damage to the quality of water need to support them through various frameworks such as payment for environmental services, which requires establishment of upstream and downstream institutional linkages. 


\section{Conclusion and recommendations}

Despite the limited data availability, the study demonstrated that soil erosion causes an immediate harm to the income of farm households. The magnitude of the effect is higher in areas with more fertile soil than those that have experienced severe degradation. This suggests that priority in soil and water conservation planning, relative priority should be given to the 'high potential' areas where productivity should be maintained. However, farmers in such areas may be reluctant to take actions since the effect may not be apparent in the short term. Empirical evidences showing the cost of no action in financial terms may be used to alert the land users and policy makers alike for action. In quantifying the paybacks of conservation measures, the inputs required and the negative impacts of the measures such as land taken out of production due to the physical structures need to be considered. Although this and many other studies reveal economic justification for land users to implement improved land and water management practices, a mechanism through which the other stakeholders that benefit from the improvement should be in place. Such mechanism enhances the coordination between upstream and downstream land and water users towards avoiding the negative impacts of no action.

Acknowledgements. This study was financially supported by the Challenge Program on Water and Food (CPWF) and the CGIAR Humidtropics programme. Yenenesh Abebe, GIS expert with IWMI has helped in extracting the site-specific soil and climate data for the landscape positions and in preparing maps in this paper. We also acknowledge the contribution of Mequanint Tenaw who helped in organizing and summarizing the data. We thank the anonymous reviewers for their critical and constructive comments.

Edited by: A. Jordán

\section{References}

Adimassu, Z., Mekonnen, K., Yirga, C., and Kessler, A.: Effect of soil bunds on runoff, soil and nutrient losses, and crop yield in the central highlands of Ethiopia, Land Degrad. Dev., 25, 554-564, doi:10.1002/ldr.2182, 2014.

Angassa, A.: Effects of grazing intensity and bush encroachment on herbaceous species and rangeland condition in southern Ethiopia, Land Degrad. Dev., 25, 438-451, doi:10.1002/ldr.2160, 2014.

Belay, K. T., Van Rompaey, A., Poesen, J., Van Bruyssel, S., Deckers, J., and Amare, K.: Spatial analysis of land cover changes in eastern Tigray (Ethiopia) from 1965 to 2007: are there signs of a forest transition?, Land Degrad. Dev., 25, 130-142, doi:10.1002/ldr.1153, 2014.

Blaschke, P. M., Trustrum, N. A., and Hicks, D. L.: Impacts of mass movement erosion on land productivity: a review, Prog. Phys. Geog., 24, 21-52, 2000.

Bojö, J. and Cassells, D.: Land Degradation and Rehabilitation in Ethiopia: A Reassessment, The World Bank, Washington DC,
Environmentally Sustainable Development Division, AFTES Working Paper No. 17, 48, 1995.

Bravo-Espinosa, M., Mendoza, M. E., Carló, T., Allende, N., Medina, L., Sáenz-Reyes, J. T., and Páez, R.: Effects of converting forest to avocado orchards on topsoil properties in the transmexican volcanic system, Mexico, Land Degrad. Dev., 25, 452467, doi:10.1002/ldr.2163, 2014.

Breman, H.: Soil fertility improvement in Africa: a tool for or a byproduct of sustainable production?, African Fertilizer Market, 11, 2-10, 1998.

Cerdà, A.: The influence of aspect and vegetation on seasonal changes in erosion under rainfall simulation on a clay soil in Spain, Can. J. Soil Sci., 78, 321-330, 1998.

Cerdà, A.: Aggregate stability against water forces under different climates on agriculture land and scrubland in southern Bolivia, Soil Till. Res., 36, 1-8, 2000.

Charles, H. L. and Black, T. A.: Spatial and temporal patterns in erosion from forest roads, Water Sci. Appl., 2, 165-178, 2001.

Chitale, S. V.: Discharge Measurement - Technology and Data Analysis, Hydraulics of Alluvial Streams, Central Board of Irrigation and Power, a Status Report Number 3, New Delhi, 13-24, 1974.

Conley, D. J., Paerl, H. W., Howarth, R. W., Boesch, D. F., Seitzinger, S. P., Havens, K. E., Lancelot, C., and Likens, G. E.: Controlling eutrophication: nitrogen and phosphorus, Science, 323, 1014-1015, doi:10.1126/science.1167755, 2009.

Deckers, J. and Amare, K.: Spatial analysis of land cover changes in eastern Tigray (Ethiopia) from 1965 to 2007: are there signs of a forest transition?, Land Degrad. Dev., doi:10.1002/ldr.2275, online first, 2014.

Erkossa, T., Stahr, K., and Gaiser, T.: Effect of methods of land preparation on runoff, and soil and nutrient loss from a Vertisol in the Ethiopian highlands, Soil Use Manage., 21, 253-259, 2005.

Erkossa, T., Awulachew, S. B., and Hagos, F.: Characterization and productivity assessment of the farming systems in the upper part of the Nile Basin, Ethiop. J. Nat. Resour., 1, 149-167, 2009.

Erkossa, T., Fisseha, I., and Stahr, K.Tillage effects on Sediment Enrichment, Soil Quality and Crop Productivity in Ethiopian Highlands, Austr. J. Soil Res., 44, 753-758, 2006.

Deckers, J. and Amare, K.: Spatial analysis of land cover changes in eastern Tigray (Ethiopia) from 1965 to 2007: are there signs of a forest transition?, Land Degrad. Dev., doi:10.1002/ldr.2275, online first, 2014.

FAO and UNEP: The future of our land: facing the challenges, Guidelines for sustainable management of land resources, Food \& Agricultural Organization and United Nations Environment Program, Rome, Italy, 1999.

Gary, W. C. and Carmen, V.: Impacts of land use changes on runoff generation in the east branch of the brandywine creek watershed using a GIS-based hydrologic model, Middle States Geographer, 40, 142-149, 2007.

Getnet, T., Enyew, A., and Erkossa, T.: Characteristics and estimated onsite costs of sediment lost by Runoff from Mizewa Catchments, Blue Nile Basin, Nile Basin Development Challenge (NBDC) Science Workshop, Addis Ababa, Ethiopia, 9-10 July 2013, 105-108, 2013.

Gizawchew, A.: Soil erosion assessment: Approaches, magnitude of the problem and issues on policy and strategy development (Region 3), paper presented at the Workshop on Regional Natural 
Resources Management Potentials and Constraints, Bahir Dar, Ethiopia, 11-13 January 1995, Bureau of Natural Resources and Environmental Protection, Bahir Dar, Ethiopia, 9 pp., 1995.

Haileslassie, A., Priess, J., Veldkamp, E., Teketay, D., and Lesschen, J. P.: Assessment of soil nutrient depletion and its spatial variability on smallholders' mixed farming systems in Ethiopia using partial versus full nutrient balances, Agr. Ecosyst. Environ., 108, 1-16, 2005.

Haileslassie, A., Priess, J., Veldkamp, E., and Lesschen, J. P.: Smallholders' soil fertility management in the Central Highlands of Ethiopia: implications for nutrient stocks, balances and sustainability of agroecosystems, Nutr. Cycl. Agroecosyst., doi:10.1007/s10705-006-9017-y, 2006.

Harden, C. P.: Soil erosion and sustainable mountain development: experiments, observations, and recommendations from the Ecuadorian Andes, Mt. Res. Dev., 21, 77-83, 2001.

Hartantoa, H., Prabhub, R., Widayat, A., and Asdakd, C.: Factors affecting runoff and soil erosion: plot-level soil loss monitoring for assessing sustainability of forest management, Forest Ecol. Manag., 180, 361-374, 2003.

Henao, J. and Baanante, C.: Estimating Rates of Nutrient Depletion in Soils of Agricultural Lands of Africa, International Fertilizer Development Center, Muscle Shoals, Alabama 35662, USA, 1999.

Herweg, K. and Stillhardt, B.: The variability of soil erosion in the Highlands of Ethiopia and Eritrea, Research Report 42, Centre for Development and Environment, University of Berne, Switzerland, 1999.

Hurni, H.: Land degradation, famines and resource scenarios in Ethiopia, in: World Soil Erosion and Conservation, Cambridge University Press, Cambridge, 27-62, 1993.

IFPRI: Maize Value Chain Potential in Ethiopia: Constraints and opportunities for enhancing the system, International Food Policy Research Institute, Sustainable solutions for ending hunger, 2010.

Kertész, Á.: The global problem of land degradation and desertification, Hungarian Geographical Bulletin, 58, 19-31, 2009.

Lal, R.: Soil erosion impact on Agronomic productivity and environment quality, Crit. Rev. Plant Sci., 17, 319-464, 1998.

Lal, R.: Managing soils for feeding a global population of 10 billion, J. Sci. Food Agr., 86, 2273-2284, 2006.

Leh, M., Bajwa, S., and Chaubey, I.: Impact of land use change on erosion risk: and Integrated remote sensing geopraphic information system and modeling methodology, Land Degrad. Dev., 24, 409-421, doi:10.1002/ldr.1137, 2013.

Leh, M., Bajwa, S., and Chaubey, I.: Impact of land use change on erosion risk: and integrated remote sensing geographic information system and modeling methodology, Land Degrad. Dev., 24, 409-421, doi:10.1002/ldr.1137, 2013.

Lewis Jr., W. M., Wurtsbaugh, W. A., and Paerl, H. W.: Rationale for control of anthropogenic nitrogen and phosphorus to reduce eutrophication of inland waters, Environ. Sci. Technol., 45, 300$305,2011$.
Maiti, S. K.: Handbook of Methods in Environmental Studies, Vol. 1, Water and Wastewater Analysis Centre of Mining Environment, Indian School of Mines Dhanbad-826 004, Jaipur, India, 2004.

Montgomery, D. R.: Soil erosion and agricultural sustainability, P. Natl. Acad. Sci. USA, 104, 13268-13272, 2007.

Olsen, S. R. and Sommers, L. E.: Phosphorus, in: Method of Soil Analysis. II. Chemical and Microbiological Properties, Agronomic Monograph, Vol. 9, 2nd edn., edited by: Page, A. L., Miller, R. H., and Keeny, D. R., SSSA, Madison, Wisconsin, 295-324, 1982.

Pathak, P., Wani, S. P., Singh, P., and Sudi, R.: Sediment flow behavior from small agricultural watersheds, Agr. Water Manage., 67, 105-117, 2004.

Patnaik, P.: Handbook of Environmental analysis. Chemical Pollutants in Air, Water, Soil and Solid Wastes, CRC press, Boca Raton, London, New York, 2010.

Pimentel, D. and Burgess, M.: Soil erosion threatens food production, Agriculture, 3, 443-463, 2013.

Quinton, J. N. and Catt, J. A.: The effects of minimal tillage and contour cultivation on surface runoff, soil loss and crop yield in the long-term Woburn Erosion Reference Experiment on sandy soil at Woburn, England, Soil Use Manage., 20, 343-349, 2004.

Sunday, E. O., Mohammed, M. B., John, C. N., Hermansah, Y. W., Charles, A., and Toshiyuki, W.: Soil degradation-induced decline in productivity of sub-Saharan African soils: the prospects of looking downwards the lowlands with the Sawah ecotechnology, Applied and Environmental Soil Science, 2012, 673926, doi:10.1155/2012/673926, 2012.

Telles, T. S., Dechen, S. C. F., de Souza, L. G. A., and Guimarães, M. F.: Valuation and assessment of soil erosion costs, Sci. Agr., 70, 209-216, 2013.

Tesfahunegn, G. B.: Soil quality indicators response to land use and soil management systems in northern Ethiopia's catchment, Land Degrad. Dev., doi:10.1002/ldr.2245, online first, 2013.

Verstraeten, G. and Poesen, J.: Estimating trap efficiency of small reservoirs and ponds: methods and implications for the assessment of sediment yield, Prog. Phys. Geog., 24, 219-251, 2000.

Wu, X. Y., Zhang, L.P, and Yu, X. X.: Impacts of surface runoff and sediment on nitrogen and phosphorus loss in red soil region of southern China, Environ. Earth Sci., 67, 1939-1949, 2012.

Wudneh, A., Erkossa, T., and Devi, P.: Sediment and nutrient lost by runoff from two watersheds, Diga district in Blue Nile basin, Ethiopia, Afr. J. Environ. Sci. Technol., 8, 498-510, 2014.

Young, A.: Land degradation in South Asia: its severity, causes, and effects upon the people, Final report, Economic and Social Council, FAO, UN, Rome, 1993.

Zhao, G., Mu, X., Wen, Z., Wang, F., and Gao, P.: Soil erosion, conservation, and eco-environment changes in the Loess Plateau of China, Land Degrad. Dev., 24, 499-510, doi:10.1002/ldr.2246, 2013. 